\title{
The Potential of Giving Silage Feed Based on Corn Plant Waste (Zea mays) Using Local Microorganisms (Indigenous Microorganism) Against the Percentage of Non-Carcass on Local Sheep
}

\author{
Bahari Ryansyah Hasibuan, A H Daulay, Hasnudi, M Tafsin, Yunilas" \\ ${ }^{1}$ Animal Production Study Program, Faculty of Agriculture, Universitas Sumatera Utara, Medan \\ 20155 Indonesia \\ *Email: yunilas11@yahool.com
}

\begin{abstract}
This study aims to examine the effect of complete corn waste based on silage feed on the percentage of non carcasses on local sheep. The study was conducted at the Laboratory of Animal Biology at the University of North Sumatra in May - August 2018. The design used was a Completely Randomized Design (CRD) with 4 treatments and 3 replications using sheep with an average initial weight of $11.2 \pm 0.4 \mathrm{~kg}$. The treatments consisted of four levels of complete silage feed based on corn waste P1 (20\%), P2 (40\%), P3 (60\%), and P4 (80\%).The parameters observed were: weight, head, foot, skin, tail, trachea and lungs, liver, heart, blood, and digestive tract.The results showed that complete feed based corn waste silage did not have a significant effect $(\mathrm{P}>0.05)$ on the percentage of non-carcass weight such as skin, tail, trachea and lungs, blood and digestive tract, but gave a non-significant effect on the percentage non carcass weights such as head, feet, heart and liver. The conclusion of complete feed silage based on corn waste can have a significant influence on the internal non carcass (liver and heart) and external (head and foot) parts of male local sheep. In addition it gives a non significant influence on the non-internal carcass parts (trachea and lungs, blood and digestion) and the external (skin and tail) of male local sheep.
\end{abstract}

Keywords: corn plant waste, fermented, indigenous microorganism

Received 19 June 2019| Revised 27 June 2019| Accepted 1 August 2019 


\section{Introduction}

Utilization of agricultural industrial waste is one way to find alternative feed ingredients for livestock, especially the use of corn waste. From the data [1] it was known that the harvested area of maize was around 243,772 ha, Production was 1,519,407 tons and the average production is $62,33 \mathrm{kw} / \mathrm{ha}$. According to [2], corn waste included $50 \%$ stems, $20 \%$ leaves, $10 \%$ shells and $20 \%$ corn cobs which are potential sources of feed ingredients because they are available throughout the year.

Ruminant is able to convert low-quality feed into high-value fermented products in the rumen, but its use as animal feed is not optimal because corn waste is classified as lowquality fiber feed, its digestibility and palatability is low. Therefore, so that the nutritional value and digestibility can be improved, processing needs to be done. One way to improve feed quality is silage technique [3].

The basic principle of making silage is forage fermentation by microbes which produce a lot of lactic acid or often known as LAB. The most dominant microbes are BAL homofermentative groups which are capable of fermentation in aerobic and anaerobic conditions.Lactic acid produced during fermentation acts as a preservative that can prevent forage from damage or attack by decay bacteria [4].

MOIYL is an indigenous microorganism based on oil palm plantation waste containing bacteria, fungi and yeast in the form of Bacillus sp YLB1, Trichoderma sp YLF8 and Saccharomyces sp YLY3 including microbes that have a high ability to degrade fiber (lignocellulose). Through the exploration of indigenous microbes, multi enzymes will be produced which play a role in the feed processing. Processing fermented feed using indigenous microbes will optimize the ability of rumen microorganisms to digest high fibrous feed [5], [6].

Based on this, the author wishes to carry out research to find out how much the role of local microorganisms as probiotics MOIYL in degrading fiber so that it can improve feed quality better and be able to improve the quality of non carcasses from male local sheep.

\section{Methods}

This research was conducted at the Laboratory of Animal Biology, University of North Sumatra. This research lasted for 3 months which was conducted from May to August 2018.

The ddan material used was 12 male local sheep with an average weight of $11.2 \pm$ $0.4 \mathrm{~kg}$. Feed ingredients in the form of: Silage from corn waste, coconut meal, soybean meal, fish flour, rice bran, molasses, urea, salt and minerals, moiyl probiotics, vitamin B complex, drugs - worms, drinking water and rhodalon as disinfectants. Enclosures of 12 bulkheads measuring $1 \times 1 \mathrm{~m} 2$ along with their fittings, scales with a capacity of $50 \mathrm{~kg}$, scales with a capacity of $5 \mathrm{~kg}$, plastic sheeting, sickles, chopper. 
The research design used was RAL (Completely Randomized Design) consisting of 4 treatments 3 replications.

P1: $20 \%$ complete silage in the ration

P2: $40 \%$ complete silage in the ration

P3: $60 \%$ complete silage in the ration

P4: $80 \%$ complete silage in the ration

\subsection{Implementation of Research}

\subsubsection{Complete Silage Feed Making Process of Corn Plant Waste}

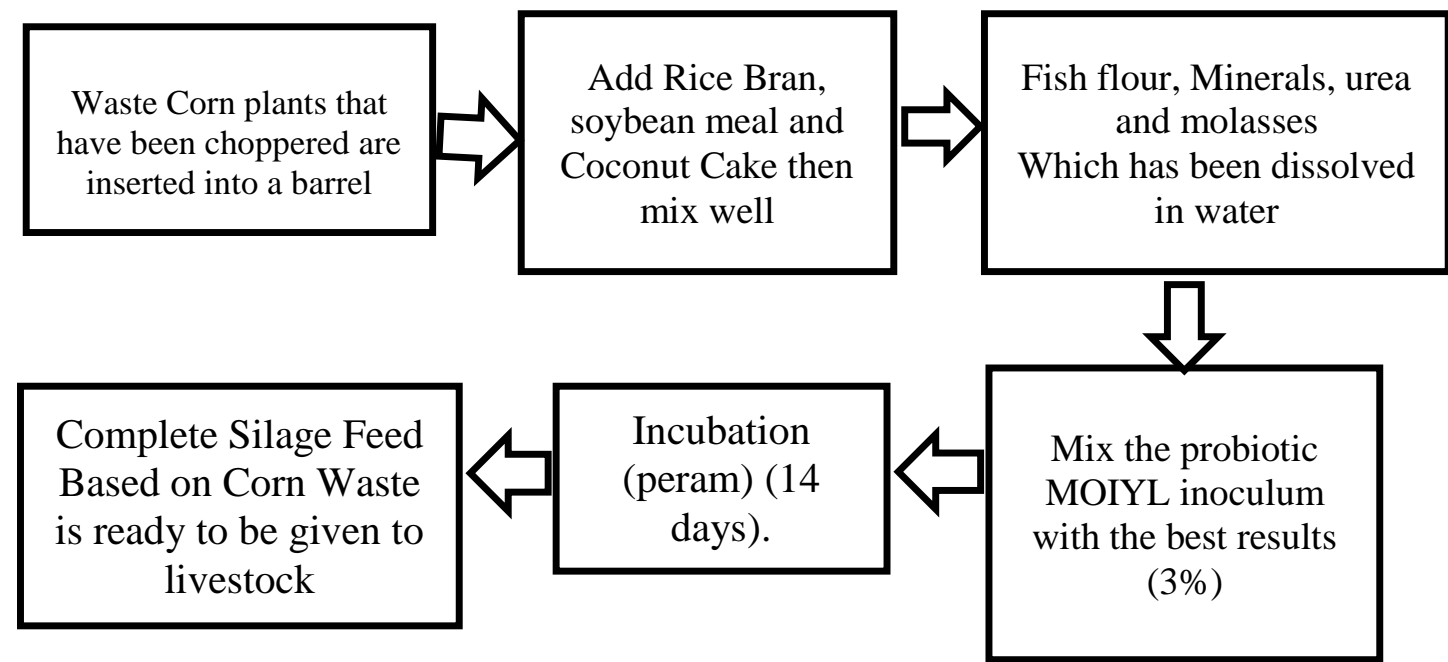

Silage Scheme of Corn Plant Waste [6]

\subsubsection{Implementation of Research}

\section{Cage Preparation}

Enclosures and all equipment used as a feed and drinking place are cleaned with a disinfectant solution.

\section{Randomization of Sheep}

The sheep used in this study were 12 animals. Placement of sheep with a random system aims that each sheep get the same opportunity by not distinguishing the body weight of the sheep. Previously weighing sheep body was carried out.

\section{Giving of Feed and Drinking Water}

Feed given is feed in the form of flour where all feed ingredients used are made in the form of concentrate feed as much as $2 \%$ of body weight and accompanied by 
the provision of silage of corn waste in the form of $10 \%$ of body weight. Feed is given in the morning at $08.00 \mathrm{WIB}$ and in the afternoon at 16.00. The remaining feed is weighed in the morning the next day just before the animals are fed again to find out the livestock consumption. Before the research was conducted, it was given time to adapt for 1 week by giving it little by little. Provision of drinking water is given adlibitum, water is replaced every day and the place is washed clean.

\section{Giving Medicines}

The first sheep cattle entered the cage were given worm medicine before the study began. While other drugs are given when sheep are sick.

Data analysis

Data obtained from research results including feed consumption, body weight gain, and feed conversion were analyzed based on a completely randomized design (CRD).

\section{Results and Analysis}

\subsection{Average Weight of Head}

Table 1. Average head weight (gr)

\begin{tabular}{|c|c|c|c|c|}
\hline \multirow{2}{*}{ Treatment } & \multicolumn{3}{|c|}{ Repeat } & \multirow{2}{*}{ Average } \\
\hline & U1 & $\mathrm{U} 2$ & $\mathrm{U} 3$ & \\
\hline $\mathrm{P} 1$ & 86.90 & 87.60 & 85.10 & $86.53^{b}$ \\
\hline $\mathrm{P} 2$ & 87.50 & 88.18 & 88.43 & $88.04^{\mathrm{ab}}$ \\
\hline $\mathrm{P} 3$ & 88.70 & 87.36 & 88.38 & $88.15^{\mathrm{ab}}$ \\
\hline $\mathrm{P} 4$ & 89.25 & 89.68 & 89.42 & $89.45^{\mathrm{a}}$ \\
\hline Total & 325.35 & 352.82 & 351.33 & 325.17 \\
\hline Average & 88.09 & 88.20 & 87.83 & 88.04 \\
\hline
\end{tabular}

In the above table it can be seen that the highest sheep head weight is in treatment P4 (80\% complete feed silage $+20 \%$ concentrate) which is equal to $89.45 \mathrm{gr}$ and the lowest sheep head weight is at treatment P1 (20\% complete feed silage $+80 \%$ concentrate) that is equal to 86.53 gr.

To find out the effect of complete silage based corn feed silage on head weight can be seen in Table 2 .

Table 2. Analysis of the variety of male local sheep head weights

\begin{tabular}{lllllll}
\hline SK & Db & JK & KT & F. Hit & F 0.05 & F 0.01 \\
\hline Treatment & 3 & 12.9386166 & 3.2346541 & $4.78^{*}$ & 4.07 & 7.59 \\
Error & 8 & 7 & 7 & & & \\
& & 4.73315000 & 0.6761642 & & & \\
\hline Total & 11 & 17.6717666 & & & & \\
\hline
\end{tabular}

Note: $*=$ Real 
From the results of the study it can be seen that Fcount is greater than $\mathrm{F}$ Table ( $\mathrm{P}<0.05)$ so it can be concluded that complete feed silage based on MOIYL fermented corn waste gave a significant effect on head weight in sheep. This is because the head is a component that experiences growth at the beginning of life so that at the stage of growth the weight gain of the head is not significant, this is in accordance with statement [7] stating that the head is a component that experienced large growth at the beginning of life, but decreased growth in end of life.

\subsection{Average Leg Weight}

Table 3. Average foot weight (gr)

\begin{tabular}{ccccc}
\hline \multirow{2}{*}{ Treatment } & \multicolumn{3}{c}{ Repeat } & \multirow{2}{*}{ Average } \\
\cline { 2 - 4 } & U1 & U2 & U3 & \\
\hline P1 & 38.54 & 36.71 & 36.96 & $37.40^{\mathrm{b}}$ \\
P2 & 38.87 & 38.70 & 38.28 & $38.62^{\mathrm{b}}$ \\
P3 & 37.97 & 38.64 & 38.14 & $38.25^{\mathrm{b}}$ \\
P4 & 39.27 & 40.29 & 41.65 & $40.40^{\mathrm{a}}$ \\
\hline Total & 154.64 & 154.34 & 155.03 & 154.67 \\
\hline Average & 38.66 & 38.58 & 38.76 & 38.67 \\
\hline
\end{tabular}

In the table above, it can be seen that the highest average leg weight of sheep is in treatment $\mathrm{P} 4$ ( $80 \%$ complete feed silage $+20 \%$ concentrate) that is equal to $40.40 \mathrm{gr}$ and the lowest sheep head weight is at treatment P1 $(20 \%$ complete feed silage $+80 \%$ concentrate ) that is equal to $37.40 \mathrm{gr}$.

To determine the effect of complete silage feed based on corn waste on foot weight can be seen in Table 4 .

Table 4. Analysis of the variance in the weight percentage of male local sheep

\begin{tabular}{lllllll}
\hline SK & Db & JK & KT & F. Hit & F 0.05 & F 0.01 \\
\hline Treatment & 3 & 14.3824166 & 3.5956041 & $4.81^{*}$ & 4.07 & 7.59 \\
Error & 8 & 7 & 5.22975000 & 0.7471071 & & \\
\\
\hline Total & 11 & 19.6121666 & & & \\
& & 7 & & & & \\
\hline
\end{tabular}

Note $: *$ Real

From the results of the study it can be seen that Fcount is greater than F Table (P $<0.05)$ so that it can be concluded that the complete feed silage based on MOIYL fermented corn waste gave a significant effect on leg weight in sheep. This is because the foot is a component that experiences growth at the beginning of life and high consumption of nutrients influences the growth of foot weight. This is in accordance with the statement [7] in [8], stating that the head and feet are components that experience large growth at the beginning of life, but experience a decline in growth at the end of life. [9], states that consumption of high nutrition affects foot weight at the same body weight. 
3.3 Average Skin Weight

Table 5. Average skin weight (gr)

\begin{tabular}{ccccc}
\hline \multirow{2}{*}{ Treatment } & \multicolumn{3}{c}{ Repeat } & \multirow{2}{*}{ Average } \\
\cline { 2 - 4 } & $\mathrm{U} 1$ & $\mathrm{U} 2$ & $\mathrm{U} 3$ & \\
\hline P1 & 130.82 & 112.21 & 121.81 & $121.61^{\mathrm{tn}}$ \\
P2 & 150.36 & 134.46 & 144.64 & $143.15^{\mathrm{tn}}$ \\
P3 & 140.71 & 136.0 & 144.24 & $140.32^{\mathrm{tn}}$ \\
P4 & 157.26 & 136.35 & 153.10 & $148.90^{\text {tn }}$ \\
\hline Total & 579.15 & 519.02 & 563.79 & $553.98^{\text {tn }}$ \\
\hline Average & 144.79 & 129.755 & 140.94 & $138.495^{\text {tn }}$ \\
\hline
\end{tabular}

From the table above it can be seen that the highest average weight of sheep skin which is complete silage based on corn waste is found in treatment P4 ( $80 \%$ complete feed silage $+20 \%$ concentrate) which is 148.90 gr and the lowest weight is in treatment $\mathrm{P} 1(20 \%$ silage complete feed $+80 \%$ concentrate) that is equal to $121.61 \mathrm{gr}$

To find out the effect of complete feed silage on skin weight can be seen in Table 6.

Table 6. Analysis of the variety of skin weights in male local sheep

\begin{tabular}{ccccccc}
\hline SK & Db & JK & KT & F. Hit & F 0.05 & F 0.01 \\
\hline Treatment & 3 & 1284.519000 & 321.129750 & $4.07^{\text {tn }}$ & 4.07 & 7.59 \\
Error & 8 & 552.666067 & 78.982295 & & & \\
\hline Total & 11 & 1837.185067 & & & & \\
\hline
\end{tabular}

Note:nr $=$ Not Real

From the results of the study it can be seen that the F count is smaller than F Table $(\mathrm{P}>0.05)$ so it can be concluded that the complete silage feed based on MOIYL fermented corn waste did not have a significant effect on skin weight in local sheep. This is because the increase in cutting weight is closely related to the weight of the skin, where the greater the weight of the cut the greater the weight percentage of the skin because the greater the weight of the cut the area and volume of the skin will be greater. This is in accordance with the statement [7], indicating that the weight of the skin and the volume of blood in the sheep are proportional to the weight of the cut.

\subsection{Average Body Weight}

Table 7. Average body weight percentage (gr)

\begin{tabular}{ccccc}
\hline \multirow{2}{*}{ Treatment } & \multicolumn{3}{c}{ Repeat } & \multirow{2}{*}{ Average } \\
\cline { 2 - 4 } & $\mathrm{U} 1$ & $\mathrm{U} 2$ & $\mathrm{U} 3$ & \\
\hline P1 & 3.84 & 3.25 & 2.84 & $3.31^{\text {tn }}$ \\
P2 & 3.79 & 2.94 & 3.53 & $3.42^{\text {tn }}$ \\
P3 & 4.29 & 3.70 & 3.36 & $3.78^{\text {tn }}$ \\
P4 & 3.58 & 3.83 & 4.68 & $4.03^{\text {tn }}$ \\
\hline Total & 15.5 & 13.72 & 14.41 & 14.54 \\
\hline Average & 3.87 & 3.43 & 3.60 & 3.63 \\
\hline
\end{tabular}


From Table 7 it can be seen that the highest average sheep weight given complete corn-based silage feed is found in treatment P4 (80\% complete feed silage $+20 \%$ concentrate) which is equal to $4.03 \mathrm{gr}$ and the lowest sheep weight is in treatment P1 (feed silage complete $20 \%$ + concentrate $80 \%$ ) that is equal to 3.31 gr.

To find out the effect of complete feed silage on tail weight can be seen in Table 8.

Table 8 . Analysis of variety of body weights on local sheep

\begin{tabular}{ccccccc}
\hline Sk & Db & JK & KT & F. Hit & F 0.05 & F 0.01 \\
\hline Treatment & 3 & 1.1381375 & 0.2845343 & & & \\
& & 0 & 8 & $1.08^{\text {tn }}$ & 4.07 & 7.59 \\
Error & 8 & 1.8441541 & 0.2634506 & & & \\
Total & 11 & 7 & 0 & & & \\
\hline
\end{tabular}

Note: $\mathrm{nr}=$ Not Real

From the results of the study it can be seen that the $\mathrm{F}$ count is smaller than $\mathrm{F}$ Table $(\mathrm{P}>0.05)$ so it can be concluded that complete feed silage based on MOIYL fermented corn waste did not have a significant effect on tail weight in local sheep. This is suspected because the sheep used are local sheep so that the fat is not in the tail, but in other parts such as the viscera. This is in accordance with statement [7], which states that fat deposition in local sheep is not in the tail, but in other parts such as the viscera and the lower part of the skin.

\subsection{The Trachea And Lung Weight Index}

Table 9. Average tracheal and lung weight (gr)

\begin{tabular}{ccccc}
\hline \multirow{2}{*}{ Treatment } & \multicolumn{3}{c}{ Repeat } & \multirow{2}{*}{ Average } \\
\cline { 2 - 4 } & $\mathrm{U} 1$ & $\mathrm{U} 2$ & $\mathrm{U} 3$ & \\
\hline P1 & 14.52 & 16.85 & 16.93 & $16.01^{\text {tn }}$ \\
P2 & 17.20 & 17.67 & 16.91 & $17.26^{\text {th }}$ \\
P3 & 17.64 & 16.89 & 18.06 & $17.53^{\text {tn }}$ \\
P4 & 18.40 & 18.28 & 17.26 & $17.98^{\text {tn }}$ \\
\hline Total & 67.76 & 69.69 & 69.16 & 68.78 \\
\hline Average & 16.94 & 17.42 & 17.29 & 17.19 \\
\hline
\end{tabular}

From Table 9, it can be seen that the average tracheal weight and the highest lung lung given complete corn-based silage feed is found in treatment P4 ( $80 \%$ complete feed silage $+20 \%$ concentrate) which is $17.98 \mathrm{gr}$ and tracheal weight and sheep lungs the lowest is in treatment P1 (complete $20 \%$ silage feed + $80 \%$ concentrate) that is equal to $16.01 \mathrm{gr}$. To find out the effect of complete feed silage on trachea and lung weights can be seen in Table 10. 
Table 10. Analysis of the variety of tracheal and lung weights in male local sheep

\begin{tabular}{ccccccc}
\hline Sk & Db & JK & KT & F. Hit & F 0.05 & F 0.01 \\
\hline Treatment & 3 & 6.0340250 & 1.5085062 & & & \\
& & 0 & 5 & $2.00^{\text {tn }}$ & 4.07 & 7.59 \\
Error & 8 & 5.2844000 & 0.7549142 & & & \\
Total & 11 & 0 & 9 & & & \\
\hline
\end{tabular}

Note: $\mathrm{nr}=$ Not Real

From the results of the study it can be seen that the F count is smaller than F Table (P.050.05) so it can be concluded that complete feed silage based on MOIYL fermented corn waste did not have a significant effect on trachea and lung weight in local sheep. This is because the trachea and lungs are a vital tool for the body so that the difference in nutrition of the treated feed affects the percentage of tracheal and lung weight. [10], states that the increase in the weight percentage of the tracheal and pulmonary component in real non-carcasses is quantitatively caused by increased metabolic activity with increased consumption of nutrients.

\subsection{Average Weight of the Heart}

Table 11. Average liver weight (gr)

\begin{tabular}{ccccc}
\hline \multirow{2}{*}{ Treatment } & \multicolumn{3}{c}{ Repeat } & \multirow{2}{*}{ Average } \\
\cline { 2 - 3 } & $\mathrm{U} 1$ & $\mathrm{U} 2$ & $\mathrm{U} 3$ & \\
\hline P1 & 24.78 & 25.70 & 23.44 & $24.64^{\mathrm{b}}$ \\
P2 & 26.17 & 25.58 & 25.24 & $25.66^{\mathrm{ab}}$ \\
P3 & 25.03 & 24.94 & 25.20 & $25.06^{\mathrm{b}}$ \\
P4 & 27.20 & 26.35 & 27.29 & $26.95^{\mathrm{a}}$ \\
\hline Total & 103.18 & 102.57 & 101.17 & 102.31 \\
\hline Average & 25.79 & 25.64 & 25.29 & 25.58 \\
\hline
\end{tabular}

From Table 11 it can be seen that the highest sheep liver weight given complete corn-based silage feed is found in treatment P4 (80\% complete feed silage $+20 \%$ concentrate) which is $26.95 \mathrm{gr}$ and the lowest sheep weight is in treatment P1 (complete feed silage $20 \%+80 \%$ concentrate) which is equal to $24.64 \mathrm{gr}$.

To find out the effect of complete silage feed based on corn waste on liver weight can be seen in Table 12 .

Table 12. Analysis of the variety of liver weights in male local sheep

\begin{tabular}{ccccccc}
\hline Sk & Db & JK & KT & F. Hit & F 0.05 & F 0.01 \\
\hline Treatment & 3 & 9.60147917 & 2.40036979 & $5.43 *$ & 4.07 & 7.59 \\
Error & 8 & 3.09398750 & 0.44199821 & & & \\
\hline Total & 11 & 12.69546667 & & & & \\
\hline
\end{tabular}

Note: $*=$ Real

From the results of the study it can be seen that the F count is smaller than

$\mathrm{F}$ Table $(\mathrm{P}<0.05)$ so it can be concluded that complete feed silage based on 
MOIYL fermented corn waste gave a significant effect on liver weight in local sheep. This is because the growth of internal organs such as the liver varies, meaning that each animal has a different growth of liver weight, some are slow and some experience rapid growth. In accordance with statement [9], which states that the growth patterns of the liver, kidneys and digestive tract show variation, whereas digestive and metabolic organs show large changes in weight according to their nutritional status.

\subsection{Average Heart Weight}

Table 13. Average heart weight (gr)

\begin{tabular}{ccccc}
\hline \multirow{2}{*}{ Treatment } & \multicolumn{3}{c}{ Repeat } & \multirow{2}{*}{ Average } \\
\cline { 2 - 4 } & U1 & U2 & U3 $n n$ \\
\hline P1 & 5.67 & 5.25 & 5.42 & $5.45^{\mathrm{B}}$ \\
P2 & 5.89 & 5.89 & 5.38 & $5.72^{\mathrm{B}}$ \\
P3 & 5.80 & 5.71 & 5.54 & $5.68^{\mathrm{B}}$ \\
P4 & 6.37 & 5.95 & 5.95 & $6.09^{\mathrm{A}}$ \\
\hline Total & 23.73 & 22.8 & 22.29 & 22.94 \\
\hline Average & 5.93 & 5.7 & 5.57 & 5.73 \\
\hline
\end{tabular}

From Table 13 it can be seen that the highest heart weight of sheep given complete feed silage based on corn waste was found in treatment P4 $(80 \%$ complete feed silage $+20 \%$ concentrate) which was $6.09 \mathrm{gr}$ and the lowest heart weight of the sheep was treatment P1 (complete feed silage $20 \%+80 \%$ concentrate) which is equal to $5.45 \mathrm{gr}$.

To find out the effect of complete silage feed based on corn waste on heart weight can be seen in Table 14 .

Table 14. Analysis of the variety of heart weights in male local sheep

\begin{tabular}{ccccccc}
\hline Sk & Db & JK & KT & F. Hit & F 0.05 & F 0.01 \\
\hline Treatment & 3 & 0.89536667 & 0.22384167 & $10.05^{* *}$ & 4.07 & 7.59 \\
Error & 8 & 0.15593333 & 0.02227619 & & & \\
\hline Total & 11 & 101.000 & & & & \\
\hline
\end{tabular}

Note $=$ Treatment gives a very different effect $(\mathrm{P}<0.01)$

From the results of the study it can be seen that the F count is greater than F Table ( $\mathrm{P}<0.01)$ so it can be concluded that complete silage feed based on MOIYL fermented corn waste gave a very significant effect on heart weight in local sheep. It is suspected that the feed ingredients given affect the percentage of heart weight. According to [11] in [12] stated that feed ingredients can affect the weight gain of non-carcass components of sheep which consume high-energy feed, have a heavier heart than those who consume lower energy. Coupled with [13], states that body weight and heart have a relationship that is directly proportional where the higher the body weight, the higher the weight of the heart. 


\subsection{Average Blood Weight}

Table 15. Average blood weight (gr)

\begin{tabular}{ccccc}
\hline \multirow{2}{*}{ Treatment } & \multicolumn{3}{c}{ Repeat } & \multirow{2}{*}{ Average } \\
\cline { 2 - 4 } & U1 & U2 & U3 $n n$ \\
\hline P1 & 33.37 & 29.03 & 30.86 & $31.09^{\text {tn }}$ \\
P2 & 30.62 & 30.88 & 34.58 & $32.03^{\text {tn }}$ \\
P3 & 32.84 & 30.24 & 34.02 & $32.37^{\text {tn }}$ \\
P4 & 38.08 & 30.43 & 31.11 & $33.21^{\text {tn }}$ \\
\hline Total & 134.91 & 120.58 & 130.57 & $128.7^{\text {tn }}$ \\
\hline Average & 33.73 & 30.14 & 32.64 & 32.17 \\
\hline
\end{tabular}

From Table 15 it can be seen that the highest blood weight of sheep given complete corn-based silage feed was found in treatment P4 (80\% complete feed silage $+20 \%$ concentrate) which was 33.21 gr and the lowest blood weight of sheep was treatment P1 (complete feed silage $20 \%+80 \%$ concentrate) that is equal to 31.09 gr. To find out the effect of complete feed silage on blood weight can be seen in Table 16.

Table 16. Analysis of variance in blood weight percentage in male local sheep

\begin{tabular}{ccccccc}
\hline Sk & Db & JK & KT & F. Hit & F 0.05 & F 0.01 \\
\hline Treatment & 3 & 9.27695000 & 2.31923750 & $0.27^{\text {tn }}$ & 4.07 & 7.59 \\
Error & 8 & 60.28901667 & 8.61271667 & & & \\
\hline Total & 11 & 69.5659667 & & & & \\
\hline
\end{tabular}

Note: $\mathrm{nr}=$ Not Real

From the results of the study it can be seen that the calculated $\mathrm{F}$ is greater than F Table $(\mathrm{P}>0.05)$ so it can be concluded that complete silage feed based on MOIYL fermented corn waste did not have a significant effect on blood weight in local sheep. This is because the greater the cutting weight the greater the blood weight percentage because the greater the weight of the cut, the greater the volume of blood in the whole body. This is in accordance with the statement [7], which states that skin weight and blood volume in sheep are proportional to the weight of the slaughter.

\subsection{Average Digestive Weight}

Table 17. Average digestive weight (gr)

\begin{tabular}{ccccc}
\hline \multirow{2}{*}{ Treatment } & \multicolumn{3}{c}{ Repeat } & \multirow{2}{*}{ Average } \\
\cline { 2 - 4 } & U1 & U2 & U3 & \\
\hline P1 & 173.11 & 179.71 & 171.87 & $241.68^{\text {tn }}$ \\
P2 & 177.92 & 184.01 & 193.35 & $185.09^{\text {tn }}$ \\
P3 & 180.78 & 196.24 & 182.80 & $186.61^{\text {tn }}$ \\
P4 & 193.22 & 206.99 & 188.54 & $196.25^{\text {tn }}$ \\
\hline Total & 725.03 & 766.95 & 736.56 & 809.63 \\
\hline Average & 181.26 & 191.73 & 184.14 & 202.41 \\
\hline
\end{tabular}

From Table 17 it can be seen that the highest digestive weight of the digestive tract given complete corn-based silage feed is found in treatment P1 
( $80 \%$ complete feed silage $+20 \%$ concentrate) which is $241.68 \mathrm{gr}$ and the lowest digestive weight of sheep is $\mathrm{P} 2$ treatment (silage $20 \%$ complete feed $+80 \%$ concentrate) which is equal to 185.09 gr.

To find out the effect of complete feed silage on the weight percentage of the digestive tract can be seen in Table 18 .

Table 18. Analysis of the various percentage of digestive weights

\begin{tabular}{ccccccc}
\hline Sk & Db & JK & KT & F. Hit & F 0.05 & F 0.01 \\
\hline Treatment & 3 & 704.229779 & 176.057445 & $2.65^{\text {tn }}$ & 4.07 & 7.59 \\
Error & 8 & 464.920788 & 66.417255 & & & \\
\hline Total & 11 & 1169.150567 & & & & \\
\hline
\end{tabular}

Note: $\mathrm{nr}=$ Not Real

From the results of the study it can be seen that $\mathrm{F}$ count is smaller than $\mathrm{F}$ Table $(\mathrm{P}$ (0.05) so it can be concluded that the complete feed silage based on MOIYL fermented corn waste does not have a significant effect on the digestive tract weight in local sheep. This is due to the treatment that has a significant effect on the weight of local sheep slaughter studied because the growth rate is directly proportional to the weight of the digestive tract. This is in accordance with [14], who stated that the rate of growth of several non-carcass components is almost the same as the rate of growth of the body, for example the abomasum and large intestine reach maturity almost simultaneously with the body. The small intestine grows faster than the large intestine and abomasum. The weight of the rumen, reticulum and omasum increases rapidly at the beginning of post natal life. Nevertheless the total weight of the digestive tract decreases when it reaches maturity. This is also supported by the results of the study [15] which states that the cut weight in sheep gives a different influence on the percentage of the digestive tract.

\section{Conclusions}

The provision of complete feed silage based on corn waste can have a significant effect on the internal non-carcass (liver and heart) and external (head and foot) parts of male local sheep. And gives an unrealistic influence on the non-internal carcass parts (trachea and lungs, blood and digestion) and external parts (male local skin and equator

\section{References}

[1] Badan Pusat Statistik. 2015.

[2] Basymeleh, S. 2009. Pengaruh Jenis Hijauan Pakan dan Lama Penyimpanan Terhadap Sifat Fisik Wafer. Fakultas Peternakan IPB, Bogor.

[3] Umiyasih, U. dan Y. N. Anggraeny. 2005. Evaluasi Limbah Dari Beberapa Varietas Jagung Siap Rilis Sebagai Pakan Sapi Potong. Pros. Seminar Nasional Teknologi Peternakan dan Veteriner. Bogor, 12 - 13 September 2005. Puslitbang Peternakan, Bogor. hlm. 125 - 130.

[4] Ridwan, R., S. Ratnakomala., G. Kartina, dan Y. Widyastuti. 2005. Pengaruh penambahan dedak padi dan Lactobacillus plantarum 1BL-2 dalam pembuatan silase rumput gajah (Penisetum purpureum). Jurnal Media Peternakan-IPB. 28 (3): 117-123.

[5] Yunilas, Lili Warly, Yetti Marlida., and Irsan Riyanto (2013). Potency of Indigenous Bacteria from Oil Palm Waste in Degrades Lignocellulose as A Sources of 
Inoculum Fermented to High Fibre Feed. Pakistan Journal of Nutrition. 12(9) : 851-853.

[6]Yunilas. 2016. Peran Mikroorganisme Indigenous YL (MOIYL) Sebagai Inokulum Pendegradasi Serat Berbasis Limbah Perkebunan Sawit. Prosiding Seminar nasional Peternakan Berkelanjutan 8.16 November 2016.

[7] Tobing, M.M., C. M. S. Lestari Dan S. Dartosukarno. 2004. Proporsi Karkas Dan Non Karkas Domba Lokal Jantan Menggunakan Pakan Rumput Gajah Dengan Berbagai Level Ampas Tahu. Jurnal Pengembangan Peternakan Tropis. Buku2. Hlm. 90 97.Unggas. Fakultas Pasca Sarjana UGM. Yogyakarta.

[8] Hudallah, C.M.S. Lestari Dan E. Pubowati, 2007. Persentase Karkas Dan Non Karkas Domba Lokal Jantan Dengan Metode Pemberian Pakan Yang Berbeda. Fakultas Peternakan Universitas Diponegoro. Semarang.

[9]Soeparno. 2005. Ilmu dan Teknologi Daging. Gadjah Mada University Press. Yogyakarta

[10] Soeparno, Setiyono, dan S. Djojowidagdo. 1993. Peningkatan Produksi dan Kualitas Daging Kambing. Kerjasama penelitian antara Badan Penelitian dan Pengembangan Proyek Pembangunan Penelitian Pertanian Nasional dengan Lembaga Penelitian Universitas Gadjah Mada.

[11] Ridawan, 1991. Pertumbuhan Karkas, Komponen Karkas Dan Non Karkas Kambing Kacang Dalam Berbagai Tingkat Pemberian Konsentrat. Fakultas Pasca Sarjana. IPB, Bogor.

[12] Ginting, E. P. 2013. Pemanfaatan Kulit Daging Buah Kopi yang Diamoniasi pada Pakan Domba terhadap Persentase Non Karkas Domba Lokal Jantan Lepas Sapih. Fakultas Pertanian Universitas Sumatera Utara. Medan.

[13] Musa.A.M, N.Z. Idam and K.M. Elamin. 2011 Heart Reflect Live Body Weight in Sudanese Shogur under Field Conditions. Department of Animal Breeding, Faculty of Animal Production, University of Gezira Sudan.

[14] Berg, R. T dan R. M. Butterfield, 1976. New Concepts Of Cattle Growth. Sidney University. Press, Sidney.

[15] Wisnu, W., R. Widiati dan I. G. S. Budi. 2009. Pengaruh berat potong dan harga pembeliaan domba dan kambing betina Terhadap gross margin jagal di rumah potong hewan mentik, kresen, Bantul. Fakultas Petenakan. Universitas Gadjah Mada. Yogyakarta. 